STUDIA EDUKACYJNE NR 31/2014

HANNA KRAUZE-SIKORSKA, KINGA KUSZAK

Uniwersytet im. Adama Mickiewicza

$w$ Poznaniu

\title{
EDUKACJA PRZEDSZKOLNA DZIECKA DWULETNIEGO - KONTROWERSJE I DYLEMATY. PRZYCZYNEK DO DYSKUSJI
}

\begin{abstract}
Krauze-Sikorska Hanna, Kuszak Kinga, Edukacja przedszkolna dziecka dwuletniego - kontrowersje i dylematy. Przyczynek do dyskusji [Preschool Education of Two-Year-Olds - Controversies and Dilemmas. Contribution to the Discussion]. Studia Edukacyjne nr 31, 2014, Poznań 2014, pp. 25-44. Adam Mickiewicz University Press. ISBN 978-83-232-2781-6. ISSN 1233-6688

In the article we shall discuss the education of two year old children, possibilities of a preschool opening itself to them and adapting preschool education to their developmental needs. We indicate that early care and education of a young child in a preschool can, in a particular way, influence the development of its developmental potential, provided that in the process of adaptation to the preschool environment a child will experience a sense of safety, develop curiosity of the surrounding world and the desire to establish and maintain social contacts.
\end{abstract}

Key words: two year old child, care, education, preschool education, teacher competences of a young child

\section{Wprowadzenie}

Na przestrzeni ostatnich kilku lat w dyskursie pedagogicznym koncentrującym się wokół edukacji małego dziecka wiele uwagi poświęcono zagadnieniu dojrzałości i gotowości dziecka rozpoczynającego edukację w klasie pierwszej. Podjęto liczne działania zmierzające do zweryfikowania poziomu i zakresu dojrzałości dzieci pięcioletnich, związane z realizacją zadań edukacyjnych w ramach obowiązkowego przygotowania do szkoły w oddziałach przedszkolnych ${ }^{1}$. Szeroko zakrojone w ostatnich latach były

${ }^{1}$ Np. K. Nadrowska, Pięciolatki w cieniu sześciolatków, czy sześciolatki w cieniu pięciolatków zagrożenia rozwoju starszych przedszkolaków, [w:] Edukacja matego dziecka. Konteksty rozwojowe i wychowawcze, t. 4, red. E. Ogrodzka-Mazur, U. Szuścik, J. Oleksy, Kraków 2013. 
też badania nad dziećmi sześcioletnimi, realizowane w kontekście najpierw zapowiadanej, później stopniowo wdrażanej reformy edukacji, której konsekwencją było wzbudzające wiele kontrowersji wśród pedagogów i rodziców obniżenie wieku szkolnego dzieci². Weryfikacjom empirycznym towarzyszyły, i ciągle towarzyszą, próby konstruowania rozwiązań praktycznych zmierzających do:

- (bardziej efektywnego/bezpiecznego) przygotowania dziecka do podjęcia roli ucznia na terenie przedszkola;

- (bardziej efektywnego/bezpiecznego) badania poziomu dojrzałości/gotowości dzieci przedszkolnych do podjęcia nauki w klasie pierwszej;

- (bardziej efektywnego) przygotowania nauczyciela przedszkola do pracy z dzieckiem pięcioletnim;

- (bardziej efektywnego) przygotowania nauczyciela do pracy z młodszym uczniem;

- (bardziej efektywnego/bezpiecznego) przygotowania rodzica do rozumienia potrzeb i możliwości dziecka - małego ucznia;

- (bardziej efektywnego/bezpiecznego) przygotowania szkoły - właściwa aranżacja przestrzeni klasy, dostosowanie toalet, korytarzy, świetlic, placów zabaw do potrzeb dzieci młodszych, dobór właściwego podręcznika itp.

W dyskursie tym zdecydowanie dominuje nurt narracji koncentrujących się wokół kompetencji i efektywności nauczyciela oraz zapewnienia bezpieczeństwa dziecku i jego rodzicom. Ten bez wątpienia istotny obszar dokonujących się zmian w systemie edukacji nie jest jednak jedynym obszarem, w którym zachodzą aktualnie ważne i potrzebne zmiany. Część z nich pozostaje jednak poza głównym nurtem zainteresowań władz oświatowych, teoretyków i praktyków edukacji. Naszym zamierzeniem jest podjęcie dyskusji nad zagadnieniem podejmowanym niejako przy okazji, na marginesie rozważań nad kwestią obniżenia wieku szkolnego dzieci. W niniejszym artykule zamierzamy skoncentrować naszą uwagę na zagadnieniu edukacji przedszkolnej dzieci najmłodszych - dwuletnich. Nasze wieloletnie doświadczenia skupione wokół zagadnień edukacji elementarnej skłaniają nas do podjęcia refleksji nad możliwościami otwarcia się przedszkola na dzieci młodsze i dostosowania edukacji przedszkolnej do potrzeb rozwojowych dzieci dwuletnich.

2 Np. A. Kopik i in., Rekomendacje dla praktyki edukacyjnej. Droga edukacyjna sześciolatków szkoła czy przedszkole, Warszawa 2011; R. Kaczan, P. Rycielski, Co wiemy o sześciolatkach w szkole na podstawie badań? Warszawa 2014. 


\section{Europejska strategia usług dla najmłodszych - założenia}

W obecnym ogólnoeuropejskim dyskursie podejmowanym wokół zagadnienia opieki i edukacji dzieci najmłodszych wyraźnie daje się zauważyć tendencja do upowszechniania oferty edukacyjnej skierowanej do dzieci młodszych. W dokumentach ogólnoeuropejskich ${ }^{3}$ można znaleźć takie, które podejmują zagadnienie "usług dla najmłodszych”, a więc dotyczą dzieci, które nie są jeszcze objęte obowiązkiem szkolnym ${ }^{4}$. Wśród aktualnych założeń europejskiej strategii usług dla najmłodszych (od 0 do 6 roku życia) wskazano kwestie, które wyznaczają ramy dla rozwiązań najbardziej optymalnych na poziomie poszczególnych krajów członkowskich Unii Europejskiej. Założenia te mają postać bardzo ogólnych tez, które odnoszą się do następujących kwestii:

1. Dostępności miejsc dla wszystkich dzieci niezależnie od miejsca zamieszkania i statusu społeczno-ekonomicznego rodziców.

2. Przystępności wszystkich usług skierowanych na zaspokojenie potrzeb edukacyjnych małego dziecka, które powinny być finansowane $\mathrm{z}$ budżetu państwa.

3. Wszechstronności i holizmu jako podstawy edukacji najmłodszych.

4. Współpracy polegającej na aktywnym zaangażowaniu lokalnej społeczności w działania na rzecz najmłodszych.

5. Spójności polityki na rzecz edukacji najmłodszych w ramach jednego resortu (inaczej niż ma to miejsce w większości krajów Unii Europejskiej, gdzie edukacja dzieci najmłodszych znajduje się w obszarze odpowiedzialności dwóch resortów: jednego odpowiadającego za opiekę nad dziećmi w wieku 0-3 lata i oddzielnie odpowiedzialnego za edukację przedszkolną dzieci 3-5/6-letnich).

6. Różnorodności i prawa wyboru pozwalających osobom zróżnicowanym pod względem językowym, etnicznym, etycznym, wyznaniowym, rodzaju niepełnosprawności, orientacji seksualnej itp. na dokonanie wyboru odpowiedniej do indywidualnych potrzeb i preferencji placówki edukacyjnej.

7. Ewaluacji działań placówek edukacyjnych, która powinna być prowadzona na bieżąco i przyjmować charakter rzeczowej dyskusji, z wykorzystaniem przejrzystych i dostępnych analizie metod ewaluacji wewnętrznej i zewnętrznej. 1996.

${ }^{3}$ Np. Recommendation on Child Care 1992; Quality Targets in Services for Young Children,

4 Obowiązek szkolny dziecka w różnych krajach przypada na wiek między 4 a 7 . rokiem życia. 
8. Określonego statusu zawodowego osób zajmujących się opieką i edukacją najmłodszych, który powinien odpowiadać statusowi nauczycieli szkolnych zarówno pod względem kwalifikacji początkowych, jak i możliwości rozwoju zawodowego, płacy, a także warunków zatrudnienia.

9. Systemu edukacji, którego integralną częścią stanie się obszar usług edukacyjnych dla najmłodszych. W tym kontekście zasadne jest więc „istnienie prężnego sektora edukacji wczesnodziecięcej" 5 .

10. Wzmacniania współpracy międzynarodowej w celu tworzenia podstaw teoretycznych i programów praktycznych $\mathrm{w}$ obszarze edukacji dla najmłodszych ${ }^{6}$.

\section{Dziecko dwuletnie w polskim systemie edukacji przedszkolnej}

W polskim systemie oświaty przedszkola obejmują swoją działalnością edukacyjno-opiekuńczą dzieci w wieku od 3 do 6 lat. Przepisy wskazują jednak, że w szczególnych przypadkach dyrektor przedszkola może przyjąć dziecko młodsze - 2,5-letnie.

Wszelkie dane liczbowe dotyczące edukacji przedszkolnej w Polsce odnoszą się do dzieci między 3 a 6 rokiem życia. Można z nich wywnioskować, iż systematycznie, choć niesatysfakcjonująco, w stosunku do realnych potrzeb, postępuje proces obniżania wieku rozpoczynania przez dzieci edukacji przedszkolnej. W 2005 roku dzieci trzyletnich w przedszkolach było zaledwie $29,70 \%$, rok później - 33,10\%, w roku 2007 - 36,10\%, w kolejnym roku liczba ta zwiększyła się do 41,10\%, w roku 2009 wynosiła 49,08\%7. Sporządzony w województwie mazowieckim raport dotyczący udziału dzieci trzyletnich w edukacji przedszkolnej na przełomie lat 2008/2009 do 2012/2013 wskazuje na systematyczny wzrost liczby dzieci najmłodszych w edukacji przedszkolnej z 24465 osób do 38107 dla całego województwa. Dane dotyczące dzieci 2-2,5-letnich są prezentowane w sposób marginalny i nie pozwalają na jednoznaczne określenie udziału dzieci młodszych w edukacji na najniższym poziomie. Dostępne statystyki pokazują dane szczątkowe, często zestawione w sposób przypadkowy. Wskazują na przykład, że w roku 2012 edukację $\mathrm{w}$ przedszkolach $\mathrm{w}$ naszym kraju podjęło 26 tys. dzieci 2,5-letnich ${ }^{8}$.

${ }^{5}$ Dzieci w Europie. Ustugi dla najmłodszych - tworzenie strategii europejskiej, www.frd.org.pl, s. 12.

6 Tamże, s. 9-12.

7 Pomoc społeczna i opieka nad dzieckiem i rodzina w 2012 r., Warszawa 2013, www. gus.gov.pl, [dostęp: 29.07.2014].

${ }^{8}$ www.men.gow.pl, [dostęp: 28.07.2014]. 
Dane GUS z tego samego roku wskazują, iż w placówkach opieki nad małym dzieckiem zapewniono dzieciom najmłodszym 50 tys. miejsc, czyli o 7,7, tys. miejsc więcej niż w roku poprzednim ${ }^{9}$. Najliczniejszą grupę we wszystkich typach placówek stanowiły dzieci dwuletnie, niemal 51\%. Warto też przywołać prognozy wieloletnie, które wskazują, iż największa liczba dzieci w wieku przedszkolnym przypadnie na lata 2016-2017, a następnie zacznie systematycznie spadać. Do roku 2035 nastąpi spadek populacji dzieci w wieku przedszkolnym do $26 \%$ stanu obecnego ${ }^{10}$. Warto zwrócić jednak uwagę, że w 2012 roku Minister Edukacji Narodowej Krystyna Szumilas zapowiadała stworzenie rządowego projektu, który ma zapewnić miejsca w przedszkolach dzieciom młodszym. Jak wówczas planowano, docelowo $\mathrm{w}$ roku $2016 \mathrm{w}$ przedszkolach miały zostać zapewnione miejsca dla wszystkich dzieci w wieku 3-5 lat i dodatkowo zakładano, że „w przypadku, gdyby rodzic chciał umieścić $\mathrm{w}$ przedszkolu dziecko dwuletnie, dyrektor będzie mógł wyrazić na to zgodę"11. Dziś wiadomo, że projekt nie zostanie zrealizowany. Brak rozwiązań systemowych utrudnia dzieciom młodszym niż trzyletnie dostęp do edukacji przedszkolnej. Należy jednak zaznaczyć, że dyrektorzy placówek przyjmują wówczas dzieci młodsze warunkowo, jako że przejawiają one określony poziom samodzielności, w szczególności takie umiejętności samoobsługowe, jak: korzystanie $\mathrm{z}$ toalety, wykonywanie czynności higienicznych, samodzielne spożywanie posiłków, ubieranie się. Poszukuje się też innych rozwiązań - przez tworzenie zespołów szkolnożłobkowych lub przedszkoli z oddziałami żłobkowymi. Są to jednak działania w dalszym ciągu marginalne, ze względu na utrudnienia formalno-organizacyjne. Rodzicom dzieci poniżej trzeciego roku życia pozostaje ograniczona, ze względu na niedostatek miejsc, możliwość skorzystania z oferty instytucji opieki nad małym dzieckiem: żłobka, klubu malucha lub niani. Należy dodać, że na terenach wiejskich możliwość skorzystania z opieki nad dzieckiem do trzeciego roku życia praktycznie nie istnieje. Dane zgromadzone przez UNICEF w 2010 roku wskazują, że procentowy udział żłobków przy przedszkolach na terenach wiejskich wynosi, $0,5 \%$ ogółu placówek ${ }^{12}$. Tymczasem, wyniki amerykańskiego badania Early Childhood Longitudinal Study dowodzą, że dzieci rozpoczynające edukację przedszkolną w wieku 2-3 lat osiągają lepsze wyniki w procesie edukacji szkolnej13. Wyniki weryfi-

9 Pomoc społeczna.

10 Edukacja a demografia, [w:] Raport o stanie edukacji 2010. Społeczeństwo w drodze do wiedzy, część 1, rozdział 4, Warszawa 2011, s. 104-105.

11 www.men.gow.pl.

12 Dzieci w Polsce, Dane, liczby. Statystyki, Warszawa 2013, s. 13, www.unicef.pl

13 A. Brzezińska i in., Znaczenie edukacji przedszkolnej, Biblioteka Entuzjastów Edukacji, $2013,1$. 
kacji empirycznej wskazują też, że zaledwie 9\% dzieci, które podjęły edukację przedszkolną w wieku 2 lat powtarza klasę w szkole, podczas gdy spośód dzieci rozpoczynających naukę dopiero w klasie pierwszej jest to aż $24 \%{ }^{14}$. Analizy przeprowadzone przez Instytut Badań Edukacyjnych dowodzą, że dzieci, które miały za sobą trzyletni pobyt $\mathrm{w}$ placówce edukacji przedszkolnej charakteryzuje wyższy poziom w zakresie umiejętności czytania i umiejętności matematycznych, w porównaniu z dziećmi, które do przedszkola uczęszczały dwa lata ${ }^{15}$.

\section{Podjęcie edukacji przedszkolnej - zadanie rozwojowe małego dziecka czy kryzys rozwojowy?}

Wkraczając $\mathrm{w}$ wiek przedszkolny dziecko staje wobec nowych zadań rozwojowych, do których według Havighursta należy zaliczyć: opanowanie sprawności fizycznych koniecznych do podejmowania aktywności zabawowej, a także gier z rówieśnikami, budowanie całościowej postawy wobec siebie oraz uczenie się obcowania z rówieśnikami ${ }^{16}$. Ważne jest, w jaki sposób dziecko poradzi sobie z przekroczeniem pierwszego progu i z realizacją zadań przed nim stojących, a więc jak przystosuje się do nowej sytuacji. Pierwsza adaptacja warunkuje nastawienie dziecka do przekraczania kolejnych progów i realizacji nowych zadań rozwojowych oraz determinuje jego kolejne umiejętności adaptacyjne. J. Lubowiecka pisze, iż przystosowanie do przedszkola

oznacza aprobatę dziecka dla znoszenia zmian $\mathrm{w}$ dotychczasowych standardach jego życia, szybkie uczenie się nowych zachowań, samodzielne pokonywanie wielu trudności. Najważniejsze jest $\mathrm{w}$ tym okresie to, żeby dziecko otrzymało wsparcie dorosłych w tym wysiłku, jakąś gratyfikację za ponoszone ograniczenia i doświadczało $\mathrm{w}$ tym środowisku wielu satysfakcji ${ }^{17}$.

Jeżeli wejście $\mathrm{w}$ nowe środowisko odbywa się w sposób dający dziecku poczucie bezpieczeństwa, jednostka wypracowuje ufny stosunek do świata i otaczających ludzi, kiedy jednak wiąże się to z lękiem, strachem, poczuciem zagrożenia, gdy nie otrzyma stosownego wsparcia, w podobny sposób będzie reagowało w każdej nowej sytuacji.

14 Tamże.

15 Tamże.

${ }^{16}$ A. Brzezińska, Społeczna psychologia rozwoju, Warszawa 2000, s. 232-233.

${ }_{17}$ J. Lubowiecka, Przystosowanie dziecka do przedszkola zadaniem rozwojowym dla dziecka, [w:] Adaptacja w przebiegu życia jednostki, red. R. Michalak, Poznań 2010, s. 47. 
Właściwa realizacja zadań stojących przed dzieckiem przedszkolnym ma jednak miejsce tylko wówczas, kiedy może ono korzystać z bogatej oferty edukacyjnej w przedszkolu, gdy trafia pod opiekę specjalistów rozumiejących możliwości, potrzeby i ograniczenia małego dziecka. Ważne jest zatem, aby

środowisko edukacyjne stwarzało jak najlepsze warunki do wykorzystania przez dziecko wszystkich swoich szans rozwojowych w atmosferze stymulującej je do pokonywania różnorodnych trudności i aby te ostatnie były na miarę jego możliwości ${ }^{18}$.

Współczesne przedszkole ma bowiem, jak podkreśla I. Adamek, stwarzać możliwie najkorzystniejsze warunki rozwoju dziecka, dostarczać bodźców stymulujących, wyrównywać braki wywołane niekorzystnymi warunkami środowiskowymi ${ }^{19}$.

Podjęcie edukacji przedszkolnej stanowi sytuację, kiedy dziecko po raz pierwszy pozostaje samo wśród nowych, nieznanych osób, zarówno rówieśników jak i dorosłych. Sytuacja ta jest zdecydowanie odmienna od jego dotychczasowych doświadczeń, gdzie wszystkie jego kontakty społeczne odbywały się w obecności rodziców, dzięki rodzicom oraz przy udziale rodziców. Dziecko miało więc zaspokojoną potrzebę bezpieczeństwa. Mogło oddalać się od opiekuna, badać rzeczywistość, doświadczać, pokonywać trudności sytuacji, w której się znajdowało oraz poznawać własne ograniczenia. Poprzez różnorodne doświadczenia miało też możliwość kształtować świadomość, że potrafi poradzić sobie bez rodziców, ale równocześnie rozwijało przekonanie, że kiedy będzie tego potrzebować, otrzyma pomoc od najważniejszego opiekuna - tzw. bezpiecznej bazy. H.R. Schaffer podkreśla z kolei, iż

obiekt przywiązania pełni funkcję bezpiecznego schronienia, właśnie bezpiecznej bazy, z którego dziecko wyrusza badać środowisko i do którego może wrócić w sytuacji niepewności, czy zagrożenia ${ }^{20}$.

Jak wskazują wyniki dostępnych badań, pierwsze kontakty dziecka ze środowiskiem przedszkolnym wywołują najczęściej negatywne przeżycia emocjonalne zarówno samego dziecka, jak i jego najważniejszego opiekuna - matki.

W chwili, gdy jednostka rozpoczyna edukację przedszkolną, musi umieć radzić sobie bez obecności i pomocy najbliższych. Powinno zatem mieć

18 J. Lubowiecka, Przystosowanie psychospołeczne dziecka do przedszkola, Warszawa 2000, s. 59-60.

${ }^{19}$ I. Adamek, Podstawy edukacji wczesnoszkolnej, Kraków 2000, s. 34-40.

${ }^{20}$ H.R. Schaffer, Psychologia dziecka, Warszawa 2005, s. 139. 
w wystarczającym stopniu rozwinięte umiejętności związane z samodzielnym radzeniem sobie $\mathrm{w}$ różnych sytuacjach. Szczególnie pierwsze dni w przedszkolu wymagają od dziecka znacznych umiejętności samodzielnego zaspokojenia swoich potrzeb oraz przystosowania się do szeregu odmiennych warunków od tych, które były charakterystyczne dla jego domu rodzinnego, dla relacji z bliskimi. Współcześnie ciągle jeszcze uważa się, że proces adaptacji dziecka do przedszkola jest dla niego dużym stresem i nie należy się temu dziwić. Pojawiają się następujące zachowania:

- protest podczas rozstania z matką,

- nadmierna lękliwość,

- zachowania agresywne,

- wycofanie się z relacji społecznych,

- izolowanie się od grupy,

- niechęć do nawiązywania kontaktów z innymi ludźmi,

- symptomy psychosomatyczne,

- ucieczka z sali,

- dopytywanie się o powrót matki,

- rzucanie się na podłogę,

- kurczowe trzymanie się nauczycielki,

- małomówność

- gadatliwość,

- nadruchliwość,

- bierność,

- zachowania destrukcyjne,

- zanieczyszczanie się ${ }^{21}$

Często zapomina się, że wczesne urazy psychiczne mogą mieć wpływ na przyszłość dziecka22. Ważne jest więc umiejętne podejmowanie działań wspierających dziecko w tym trudnym dla niego momencie, który w literaturze psychopedagogicznej rozpatrywany jest często w kategoriach kryzysu rozwojowego. O kryzysie można zaś mówić wówczas, kiedy „dane zdarzenie jest postrzegane przez osobę jako trudne, beznadziejne, stanowiące zagrożenie dla jej bezpieczeństwa" 23 . Jeżeli subiektywnie odczuwana sytuacja wyda się dziecku właśnie taką zagrażającą, w konsekwencji będzie ono demonstrowało wymienione powyżej objawy, wskazujące na problemy adap-

${ }^{21}$ A. Kienig, Proces wczesnej adaptacji do przedszkola - wspieranie kompetencji społecznych małego dziecka, [w:] Wspieranie rozwoju dzieci w procesie wczesnej edukacji, red. W. Puślecki, Wrocław 2008, s. 158.

${ }^{2}$ H. Piwowarska-Krukowska, Adaptacja dzieci w przedszkolu, Wychowanie w Przedszkolu, 2007, 5, s. 47.

${ }^{23}$ B. Muchacka, Okresy krytyczne na poszczególnych etapach edukacyjnych - doświadczenie osobiste i potencjalne możliwości dziecka, [w:] Wspieranie rozwoju dzieci, s. 112. 
tacyjne. Należy podkreślić, że to $\mathrm{w}$ jakim stopniu podjęcie edukacji przedszkolnej stanie się dla dziecka przyczyną kryzysu, determinowane jest wieloma czynnikami konstruującymi tzw. dojrzałość przedszkolną dziecka, która nie zależy od wieku kalendarzowego jednostki, lecz jest wynikiem indywidualnych właściwości psychicznych i fizycznych dziecka, zależy też od szeregu warunków zewnętrznych (społecznych/sytuacyjnych) tworzonych dziecku na terenie rodziny i przedszkola. Warto w tym miejscu zwrócić uwagę, iż kryzys sytuacyjny związany $\mathrm{z}$ wejściem $\mathrm{w}$ nową przestrzeń fizyczną, społeczną i edukacyjną nakłada się na kryzys rozwojowy przypadający na drugi-trzeci rok życia, określony przez E. Eriksona jako poczucie autonomii vs poczucie wstydu i zwątpienie. Pomoc dziecku w ukształtowaniu poczucia autonomii (nie tylko w znanym kontekście sytuacyjnym, ale $\mathrm{w}$ nowych warunkach) jest $\mathrm{w}$ tym okresie niezwykle ważnym zadaniem opiekunów. Od ich zachowania i jakości wsparcia zależy, czy jednostka osiągnie poczucie kontroli nad otoczeniem. „Źle rozwiązany kryzys powoduje, że dzieci tracą zaufanie do własnych kompetencji i wykształcają poczucie nadmiernej kontroli zewnętrznej" 24 . To z kolei sprawia, że mają trudności $\mathrm{z}$ funkcjonowaniem $\mathrm{w}$ nowym środowisku - przedszkolnym - gdyż nie wierzą we własne umiejętności oraz nie potrafią kontrolować otoczenia, w którym się znajdują, co wywołuje dezorientację i poczucie bezradności.

\section{Czynniki dojrzałości przedszkolnej dziecka dwuletniego}

Wśród czynników dojrzałości przedszkolnej dziecka przedszkolnego należy wymienić trzy zasadnicze grupy.

1. Pierwsza grupa czynników wiąże się z procesami indywidualnego rozwoju jednostki. Dojrzałość przedszkolna dziecka przejawia się w różnych obszarach jego codziennego funkcjonowania, na co zwracają uwage J. Lubowiecka i M. Suświłło25. Wyraża się ona na przykład:

- sprawnością motoryczną, przejawiającą się umiejętnością utrzymywania równowagi, biegania i wspinania się;

- poszukiwaniem zainteresowania rówieśników i coraz bardziej efektywnym wchodzeniem $\mathrm{w}$ relacje $\mathrm{z}$ innymi dziećmi poza domem rodzinnym;

${ }^{24}$ R. Michalak, Adaptacja przez rozwiązywanie kryzysów rozwojowych, [w:] Adaptacja w przebiegu życia jednostki, red. R. Michalak, Poznań 2010, s. 21.

25 J. Lubowiecka, M. Suświłło, Wybrane problemy wczesnej edukacji, Olsztyn 1997, s. 18; J. Lubowiecka, Przystosowanie psychospołeczne dziecka do przedszkola, Warszawa 2000, s. 45; tejże, Trudności adaptacyjne dziecka w przystosowaniu się do przedszkola, Wychowanie w Przedszkolu, 2001,6 , s. 324 . 
- wzrostem autonomii w relacjach z matką i dążeniem do tego, aby we własnym zakresie zaspokajać swoje potrzeby oraz działać po swojemu. Warunkiem jest tu jednak właściwie ukształtowana więź między matką a dzieckiem. Trzeba ponadto pamiętać, że okresem krytycznym dla deprywacji potrzeby miłości jest okres między szóstym miesiącem a piątym rokiem życia. Dziecko pozostawione w przedszkolu bez bliskiej osoby przez dłuższy czas narażone jest na tego typu deprywację ${ }^{26}$;

- posługiwaniem się mową, w tym: budowanie mniej lub bardziej rozwiniętych zrozumiałych dla innych wypowiedzi, inicjowanie interakcji werbalnych z partnerem dorosłym i rówieśnikiem, przejmowanie tury podczas rozmowy, kończenie interakcji, tworzenie pierwszych neologizmów itp.;

- rozwinięciem potrzeb poznawczych dziecka: pojawiają się pytania jako sposób na zaspokojenie tych potrzeb;

- wyobraźnią, która uzewnętrznia się w zabawach tematycznych i zabaw na niby z użyciem ekwiwalentu.

Trzeba jednak pamiętać, że dziecko dwu-, dwuipółletnie może:

- przejawiać opór i brak umiejętności elastycznego przystosowania się do tego co nowe; dziecko potrzebuje stałości i rutynowych działań;

- przejawiać skłonność do dominacji i stawiania przed innymi wymagań oraz formułowania poleceń i rozkazów;

- mieć trudności z dokonaniem wyboru pomiędzy dwiema alternatywami;

- mieć trudności z konsekwentną realizacją swojego zamierzenia;

- nie umieć przyjąć perspektywy innej osoby, a jego myślenie cechuje egocentryzm;

- mieć trudności z kontrolowaniem i wyrażaniem emocji $\mathrm{w}$ formie społecznie akceptowanej (słaba kontrola emocjonalna jest cechą rozwojową w tym wieku).

2. Druga grupa czynników wiąże się z funkcjonowaniem najbliższego środowiska rodzinnego dziecka i można tu wymienić:

- postawy rodziców wobec dziecka; właściwe postawy oparte na pozytywnym stosunku emocjonalnym wobec dziecka sprzyjają tworzeniu relacji bezpiecznego przywiązania do opiekunów. Pozwalają na oddalanie się dziecka od nich, przy jednoczesnym zachowaniu u niego poczucia, że jest dla rodziców kimś bardzo ważnym, że w ich obecności nic złego nie może się wydarzyć, a w sytuacji trudnej można liczyć na pomoc. E. GruszczykKolczyńska i E. Zielińska zauważają, że kiedy dziecko „musi pozostać po raz pierwszy $\mathrm{w}$ przedszkolu, obserwuje się już skutki wychowania przez

26 W.D. Wall, Twórcze wychowanie w okresie dzieciństwa, Warszawa 1986, s. 125-126. 
rodziców. Nie da się cofnąć błędów wychowawczych i dziecko jest takie, jakie jest" 27 ;

- pozycję dziecka w rodzinie; za sprzyjającą osiąganiu dojrzałości przedszkolnej można uznać taką, która pozwala dziecku czuć się akceptowanym, szanowanym i bezpiecznym, ale też wiąże się z rozwijaniem poczucia odpowiedzialności za siebie i inne osoby. $Z$ kolei, pozycja dziecka wyeksponowana, związana z dużą liczbą przywilejów, nadmiernym chronieniem i wyręczaniem go, zaspokajaniem przez otoczenie wszystkich potrzeb powoduje, że jednostce trudno wejść w środowisko, w którym realizacja jej indywidualnych potrzeb jest tak samo istotna, jak zaspokojenie potrzeb innych osób;

- oczekiwania rodziców wobec dziecka i naciski na przejawianie określonych zachowań. Jeżeli oczekiwania są adekwatne do możliwości dziecka, łatwiej jemu je zrealizować, a to z kolei wpływa na poczucie własnej skuteczności dziecka. Z kolei, kiedy oczekiwania przekraczają możliwości jednostki, wszelkie próby sprostania im przynoszą niepowodzenie i przyczyniają się do kształtowania obrazu samego siebie jako osoby niezaradnej, nieskutecznej, mało wartościowej itp. Natomiast, oczekiwania zbyt niskie nie mobilizują dziecka do podejmowania wysiłku, kształtują postawy bierne u jednostek;

- doświadczenia dziecka $\mathrm{w}$ relacjach $\mathrm{z}$ innymi osobami; im więcej różnorodnych kontaktów z rówieśnikami i dorosłymi nawiąże dziecko przed podjęciem edukacji przedszkolnej, tym w większym stopniu ma możliwość nauczyć się nawiązywania i podtrzymywania interakcji społecznych w przedszkolu;

- styl komunikowania się $\mathrm{z}$ dzieckiem; im bardziej jest on $\mathrm{w}$ rodzinie otwarty, pozwalający na wyrażanie osobistych znaczeń i poznawanie perspektywy innych osób, umożliwiający negocjowanie, przekonywanie, argumentowanie, uzasadnianie i szanowanie poglądów rozmówców, tym łatwiej dziecku funkcjonować $\mathrm{w}$ relacjach $\mathrm{z}$ różnymi osobami i rozumieć ich sposób widzenia otaczającej rzeczywistości oraz przekonywać je do własnych pomysłów;

- nastawienie rodziców do przedszkola. Niezwykle istotne w procesie adaptacji dziecka dwuletniego (ale także starszego) do nowego środowiska jest nastawienie rodziców wobec przedszkola. Często przeżywają oni wątpliwości co do jakości warunków stworzonych dzieciom przez placówkę, poziomu kwalifikacji nauczycieli i personelu pomocniczego. Matki nadopie-

27 E. Gruszczyk-Kolczyńska, E. Zielińska, Wspomaganie rozwoju umystowego trzylatków i dzieci starszych wolniej rozwijających sie, Warszawa 2004, s. 27. 
kuńcze obawiają się, że inne osoby nie będą w stanie zaspokoić potrzeb dziecka $w$ takim stopniu, jak robią to same. $W$ konsekwencji modelują zachowania lękowe u swoich dzieci, przyczyniając się do ich trudności na starcie.

3. Trzecia grupa czynników wpływających na przystosowanie się dziecka do środowiska przedszkolnego to determinanty wynikające z funkcjonowania placówki i dziecka w placówce. Należy podkreślić, że niezależnie od indywidualnego momentu rozpoczęcia przez jednostkę edukacji w przedszkolu, sam fakt pójścia do niego sprzyja zachodzeniu zmian w rozwoju i funkcjonowaniu dziecka. Podjęcie przez nie roli przedszkolaka wywołuje zmianę relacji z najbliższymi, którzy stają się rodzicami dziecka przedszkolnego, zmienia się więc ich sytuacja jako jego opiekunów, którzy wspólnie z nim rozpoczynają drogę przez edukację.

Dziecko, które staje się przedszkolakiem w znaczącym stopniu poszerza swoją przestrzeń społeczną (wchodzi w szersze środowisko społeczne). Modyfikacji ulega także przestrzeń edukacyjna. Dziecko zaczyna uczyć się w sposób bardziej celowy, systematyczny i zaplanowany. Działania edukacyjne powinny być jednak dostosowane do możliwości i potrzeb rozwojowych dwulatka. Wobec dziecka podejmującego edukację $\mathrm{w}$ przedszkolu (niezależnie od jego wieku kalendarzowego) następuje wzrost wymagań $\mathrm{w}$ różnych sferach, $\mathrm{np}$. związanej z samoobsługą (dziecko nie tylko musi umieć rozebrać się i ubrać, ale też zapamiętać w co było ubrane, gdzie jest jego półeczka, wieszak, worek z paputkami itp.). Dziecko musi umieć zaspokoić we własnym zakresie część swoich potrzeb, a inne potrzeby powinno umieć przedstawić początkowo obcej osobie, jaką jest nauczycielka w przedszkolu.

Warunkiem koniecznym jest jednak uwzględnianie $\mathrm{w}$ pracy pedagogicznej z dzieckiem przedszkolnym między innymi:

- jego indywidualnych i kulturowych doświadczeń;

- jego charakterystycznych cech rozwojowych (tempa, rytmu, zróżnicowanego poziomu poszczególnych umiejętności, zdolności specjalnych, stylu poznawania rzeczywistości, integracji procesu rozwojowego);

- konieczności tworzenia warunków do zabawy i uczenia się w grupie;

- możliwości polisensorycznego eksplorowania i doświadczania świata;

- możliwości dokonywania wyborów;

- tworzenia sytuacji pozwalających na budowanie zachowania transgresyjnego ${ }^{28}$.

${ }^{28}$ H. Krauze-Sikorska, K. Kuszak, Przedszkole - obszary działań edukacyjnych i profilaktycznych, [w:] Wybrane problemy psychospołecznego funkcjonowania dzieci i młodzieży z utrudnieniami w rozwoju, red. H. Krauze-Sikorska, K. Kuszak, Poznań 2008. 


\section{Nauczyciel(ka) małego dziecka, wychowawca (wychowawczyni) czy opiekun(ka)?}

W Unii Europejskiej osoby pracujące z dziećmi w wieku przedszkolnym i młodszymi określane są mianem: pedagogów, nauczycieli, wychowawców. Obejmują oni swoimi działaniami opiekuńczymi, wychowawczymi i edukacyjnymi dzieci w wieku 0-5 lat lub 2,5/3-5/6 lat (tab. 1)

Tabela 1

Pracownicy zatrudnieni w placówkach edukacyjnych dla najmłodszych dzieci w wybranych krajach Europy

\begin{tabular}{|c|c|c|}
\hline Kraj & $\begin{array}{l}\text { Tytuł osoby pracującej } \\
\text { z małym dzieckiem }\end{array}$ & Przedział wiekowy \\
\hline Belgia & nauczyciel & $2,5-5$ lat \\
\hline Bułgaria & nauczyciel & $\begin{array}{l}\text { 3-7 lat } \\
\text { obowiązkowa klasa ze- } \\
\text { rowa dla 6-laktów }\end{array}$ \\
\hline Cypr & nauczyciel & $\begin{array}{l}3-5,8 \text { lat } \\
\text { klasa zerowa obowiąz- } \\
\text { kowo na rok przed pój- } \\
\text { ściem przez dziecko do } \\
\text { szkoły (4,8-5,8 lat) }\end{array}$ \\
\hline Dania & pedagog & $0-5$ lat \\
\hline Francja & $\begin{array}{l}\text { wychowawca/pedagog } \\
\text { nauczyciel }\end{array}$ & $\begin{array}{l}0-2 \text { lat } \\
2,5-5 \text { lat }\end{array}$ \\
\hline Grecja & nauczyciel & $2,5-5$ lat \\
\hline Hiszpania & nauczyciel & $0-5$ lat \\
\hline Holandia & nauczyciel & 4-5 lat \\
\hline Irlandia & nauczyciel & 4-5 lat \\
\hline Luksemburg & $\begin{array}{l}\text { nauczyciel edukacji wczesno- } \\
\text { dziecięcej/nauczyciel }\end{array}$ & $\begin{array}{l}\text { dla dzieci 3-letnich } \\
\text { 4-6 lat }\end{array}$ \\
\hline Łotwa & nauczyciel & $0-7$ lat \\
\hline Malta & nauczyciel & 3-5 lat \\
\hline Norwegia & pedagog & $0-5$ lat \\
\hline Polska & nauczyciel & 3-6 lat \\
\hline Portugalia & nauczyciel & $0-5$ lat \\
\hline Rumunia & nauczyciel & 3-5 lat \\
\hline Słowacja & nauczyciel & 2/3-6 lat \\
\hline Szwecja & nauczyciel & $0-5$ lat \\
\hline Wielka Brytania & nauczyciel & 3-4 lata \\
\hline Włochy & $\begin{array}{l}\text { wychowawca/pedagog } \\
\text { nauczyciel }\end{array}$ & $\begin{array}{l}0-2 \text { lata } \\
\text { 3-5 lat }\end{array}$ \\
\hline
\end{tabular}


Warto dodać, że generalnie można wyróżnić pięć modeli specjalizacji zawodowej nauczycieli dzieci przedszkolnych:

- nauczyciel edukacji wczesnodziecięcej, np. Szwecja, Słowenia, Łotwa;

- nauczyciel wychowania przedszkolnego, np. Cypr, Malta;

- nauczyciel edukacji elementarnej, np. Bułgaria, Luksemburg, Rumunia;

- pedagog społeczny, np. Dania, Luksemburg;

- wychowawca-opiekun, np. Bułgaria, Rumunia, a także Luksemburg (dla dzieci do 18 miesięcy) ${ }^{29}$.

W naszym kraju kwestie kwalifikacji nauczycieli placówek wychowania przedszkolnego regulują: Rozporządzenie Ministra Szkolnictwa Wyższego z 2 listopada 2011 r. Krajowych Ram Kwalifikacji oraz Rozporządzenia Ministra Nauki i Szkolnictwa Wyższego w sprawie standardów kształcenia przygotowującego do wykonywania zawodu nauczyciela z 17 stycznia $2012^{30}$. Współcześni nauczyciele pracujący z małym dzieckiem, poza kompetencjami merytorycznymi i metodycznymi odnoszącymi się do wiedzy, umiejętności i kompetencji społecznych, ukształtowanymi w trakcie studiów i praktyk pedagogicznych oraz zawodowych, a także dalszego doskonalenia zawodowego, powinni cechować się umiejętnością tworzenia takich sytuacji, które pozwolą dziecku (szczególnie najmłodszemu) możliwie szybko przystosować się do nowej sytuacji fizycznej, społecznej i edukacyjnej. Od nich zależy, w jakim stopniu dziecko będzie aktywne w relacjach z innymi ludź$\mathrm{mi} \mathrm{w}$ otaczającej go przestrzeni przedszkola, a także $\mathrm{w}$ środowisku pozaprzedszkolnym ${ }^{31}$. D. Chauval i A.M. Casanova zauważają, iż

nauczyciel natknie się być może na dzieci inne, niżby oczekiwał, lecz bogate we własne możliwości. Swymi działaniami nie może zamykać, powstrzymywać, przedłużać, powielać. Jego zadaniem jest otwierać, czynić tak, by narodziła się nowa istota, która odciśnie na świecie swoje własne piętno ${ }^{32}$.

W odniesieniu do dziecka podejmującego edukację $\mathrm{w}$ przedszkolu, w pierwszej kolejności pragniemy wyeksponować kompetencje opiekuńcze nauczyciela. Zwrócono na nie uwagę również w ogólnoeuropejskich założeniach strategii usług dla najmłodszych i podkreślono, iż

${ }^{29}$ Dzieci w Europie 2009, 15 (3), s. 13.

30 Wcześniej kwalifikacje nauczycieli regulowało Rozporządzenie Ministra Edukacji Narodowej z 12 marca 2009 r. w sprawie szczegółowych kwalifikacji wymaganych od nauczycieli oraz określenie szkół i wypadków, w których można zatrudnić nauczycieli nie mających wyższego wykształcenia lub ukończonego zakładu kształcenia nauczycieli.

${ }_{31}$ M. Styczyńska, Rola mężczyzny w wychowaniu dziecka w wieku przedszkolnym, [w:] Dziecko - sukcesy i porażki, red. R. Piwowarski, Warszawa 2007, s. 264.

32 D. Chauval, A.M. Casanova, Podręcznik przedszkolanki, Warszawa 1998, s. 15-16. 
opiekę należy postrzegać jako element większej całości, jako integralny i nieodłączny składnik wychowania, które polega na zapewnieniu dzieciom koniecznej przestrzeni do zabawy i nauki33.

Warto także zauważyć, iż dobry opiekun:

- tworzy sytuacje chroniące życie i zdrowie oraz zapewniające rozwój jednostce, która została powierzona jego opiece;

- podejmuje działania trafne i sprzyjające zachodzeniu korzystnych zmian rozwojowych oraz eliminujące to, co stanowi dla rozwoju zagrożenie;

- stara się, aby jego pracy opiekuńczej towarzyszyły działania mające na celu kształtowanie samodzielności podopiecznego ${ }^{34}$.

Warto dodać, że współcześnie w miejsce produktywnego modelu edukacji przedszkolnej, nastawionego na kształtowanie wyłącznie umiejętności i sprawności instrumentalnych, proponuje się model ekspresyjny, nastawiony na rozwijanie pozytywnego obrazu samego siebie, na budowanie świata wewnętrznego dziecka i umiejętności jego wyrażania, przynoszące w konsekwencji możliwość kierowania sobą ${ }^{35}$. Zatem, oprócz kompetencji opiekuńczych nauczyciel powinien ukształtować takie, które umożliwią tworzenie korzystnych warunków dla indywidualnego rozwoju każdego wychowanka. Zaliczyć do nich można:

- diagnostyczne (umiejętności i narzędzia związane dokonywaniem oceny stanu aktualnego i elementów składających się na ten stan, opartych na głębokiej wiedzy psychopedagogicznej);

- projektujące (planowanie powinno być dokonane na gruncie pogłębionej diagnozy);

- realizacyjne (twórcze kierowanie procesem zdobywania wiedzy i doświadczeń przez uczniów - animacja grupy, kreowanie przestrzeni, dobór i wytwarzanie materiałów edukacyjnych itp.);

- monitorujące (uważna obserwacja i analiza rozwoju każdego dziecka);

- ewaluacyjne (związane z umiejętnością wyciągania krytycznych wniosków dla własnych dalszych działań);

- komunikacyjno-społeczne (związane $\mathrm{z}$ funkcjonowaniem $\mathrm{w}$ bezpośrednich interakcjach nauczyciel - dziecko, nauczyciel - rodzic, nauczyciel inni nauczyciele, nauczyciel - osoby wspomagające i wspierające go $\mathrm{w}$ realizacji zadań, nauczyciel - bliższe i dalsze otoczenie szkoły);

${ }^{33}$ Dzieci w Europie, s. 10.

34 A. Ratajczak, Instytucjonalna opieka nad matym dzieckiem. Aktualny stan - perspektywy, [w:] Świat małego dziecka, t. 1, red. H. Krauze-Sikorska, M. Klichowski, K. Kuszak, Poznań 2013, s. 21.

${ }^{35}$ K. Lubomirska, Przedszkole. Rzeczywistość i szansa, Warszawa 1994, s. 174-176. 
- emocjonalne (funkcjonowanie w zawodzie nauczyciela wiąże się z przeżywaniem emocji bez względu na ich znak; często są to emocje ambiwalentne, z którymi nauczyciel musi umieć sobie poradzić).

T. Lewandowska-Kidońn ${ }^{36}$ uzupełnia ten wykaz o kompetencje:

- moralne, przejawiające się świadomością siebie i własnego systemu wartości, odpowiedzialnością za powierzone jego opiece dzieci i sprawiedliwością wobec nich, a także dojrzałością emocjonalną, zdolnością do przejawiania głębokiej refleksji moralnej;

- umiejętności współdziałania, wiążące się z umiejętnościami wspólnego $\mathrm{z}$ innymi nauczycielami działania na rzecz dzieci. W zakres tych kompetencji wchodzi też umiejętność współpracy z rodzicami dzieci (szczególnie w okresie wczesnej adaptacji, kiedy zarówno rodzice, jak i nauczyciele wymagają pomocy oraz wsparcia, jak też ustalenia jednolitego systemu oddziaływań wobec dziecka). Należy również podkreślić umiejętność współdziałania z dzieckiem już od pierwszych dni jego pobytu w placówce;

- prakseologiczne, czyli umiejętność projektowania wizji pracy z dzieć$\mathrm{mi}$, tworzenia programów wychowawczych i profilaktycznych, podejmowania działań diagnostycznych, ewaluacyjnych, związanych z mierzeniem jakości własnej pracy;

- kreatywne, pozwalające na nieustanną pracę nad sobą, uzupełnianie osobistej wiedzy, rozwijanie umiejętności zawodowych, doskonalenie własnego warsztatu pracy.

Wymienione powyżej kompetencje są niezbędne w codziennej praktyce przedszkolnej, ponieważ dziecko rozpoczynające edukację musi w stosunkowo krótkim czasie przystosować się do:

- przebywania przez dłuższy czas z obcymi osobami;

- przebywania w licznej grupie dzieci;

- przestrzegania innych niż $\mathrm{w}$ domu regul;

- innych warunków materialnych przedszkola;

- wymagań związanych ze sposobem korzystania z różnych sprzętów;

- wymagań w zakresie samoobsługi;

- wymagań związanych ze sposobami nawiązywania i podtrzymywania relacji z innymi osobami;

- innego niż w domu rozkładu dnia;

- innej niż w rodzinie pozycji społecznej ${ }^{37}$.

${ }^{36}$ T. Lewandowska-Kidoń, Kompetencje nauczyciela szkoty wspótczesnej, [w:] Nauczyciel kompetentny teraźniejszość i przysztość, red. Z. Bartkowicz, M. Kowaluk, M. Samujło, Lublin 2007, s. 188 i n.

${ }^{37}$ M. Kąkol, Z badań nad warunkami adaptacji dzieci trzyletnich do przedszkola, Wychowanie w Przedszkolu, 1988, 2, s. 68; tegoż, Z badań nad warunkami adaptacji dzieci trzyletnich w przed- 
Wymienione wyżej kompetencje nauczyciela małego dziecka wskazują, że jest on w różnym stopniu opiekunem, wychowawcą, jak i osobą organizującą aktywność edukacyjną dziecka.

\section{Podsumowanie}

Wczesna opieka i edukacja małego dziecka są w stanie w sposób szczególny wpłynąć na rozwój jego potencjału rozwojowego, pod warunkiem że $\mathrm{w}$ procesie adaptacji do środowiska przedszkolnego dziecko doświadczy poczucia bezpieczeństwa, rozwinie ciekawość świata oraz chęć do nawiązywania i podtrzymywania kontaktów społecznych. Równocześnie będzie też, zgodnie ze swoimi indywidualnymi potrzebami i posiadanym potencjałem, wspierane w uczeniu się, bo wczesne doświadczenia w tym zakresie są fundamentem wszystkich, kolejnych etapów uczenia się. W praktyce oznacza to stworzenie małemu dziecku takich warunków, które pozwolą mu zdobyć zaufanie do nowego otoczenia oraz nawiązać, przy aktywnym współudziale rodziców, więź z opiekunem - nauczycielem. Triada dzieckorodzic-nauczyciel, będący równocześnie opiekunem i wychowawcą, to podstawa "trójkąta więzi"38, sprzyjającego dobremu funkcjonowaniu dziecka w placówce przedszkolnej. Dzięki wzajemnej komunikacji nauczyciel nie tylko lepiej poznaje dziecko i może planować działania opiekuńcze, wychowawcze i edukacyjne, ale też będąc $\mathrm{w}$ stałym kontakcie $\mathrm{z}$ rodzicami jest w stanie pozyskać ich wsparcie i akceptację podejmowanych przez siebie działań. I choć edukacja przedszkolna dziecka dwuletniego nieustannie stawia przed dorosłymi nowe wyzwania, budzi wśród nauczycieli przedszkoli wątpliwości odnośnie strategii pracy z małym dzieckiem, prowokuje pytania o sens wczesnej edukacji, to najważniejsze by pamiętać, że dobra jakość wczesnej opieki i edukacji ma na dziecko wpływ, jaki trudno osiągnąć środkami wykorzystywanymi na późniejszych etapach jego życia.

\section{BIBLIOGRAFIA}

Adamek I., Podstawy edukacji wczesnoszkolnej, Oficyna Wydawnicza Impuls, Kraków 2000. Brzezińska A., Społeczna psychologia rozwoju, Wydawnictwo Scholar, Warszawa 2000.

szkolu, [w:] Adaptacja dziecka do przedszkola i szkoty, red. M. Kąkol, Szczecin 1990, s. 48; A. Kienig, Przystosowanie dzieci trzyletnich do przedszkola, [w:] Edukacja przedszkolna na przełomie tysiacleci, red. S. Guz, Warszawa 2001, s. 163.

${ }^{38}$ H. Laewen, B. Andres, E. Hedervari, Die ersten Tage in der Krippe, Heidelberg 2000. 
Brzezińska A., Czub M., Kaczan R., Rycielski P., Znaczenie edukacji przedszkolnej, Biblioteka Entuzjastów Edukacji, 2013, 1.

Chauval D., Casanova A.M., Podręcznik przedszkolanki, Wydawnictwo Cykady, Warszawa 1998.

Dzieci w Europie. Ustugi dla najmłodszych - tworzenie strategii europejskiej, www.frd.org.pl.

Dzieci w Polsce, Dane, liczby. Statystyki, Warszawa 2013, www.unicef.pl.

Edukacja a demografia, [w:] Raport o stanie edukacji 2010. Społeczeństwo w drodze do wiedzy, część 1, rozdział 4, Instytut Badań Edukacyjnych, Warszawa 2011.

Filipczuk H., Rodzina a rozwój psychiczny dziecka, Nasza Księgarnia, Warszawa 1981.

Gruszczyk-Kolczyńska E., Zielińska E., Wspomaganie rozwoju umysłowego trzylatków i dzieci starszych wolniej rozwijających się, Wydawnictwo Szkolne i Pedagogiczne, Warszawa 2004.

Kaczan R., Rycielski P., Co wiemy o sześciolatkach w szkole na podstawie badań? Instytut Badań Edukacyjnych, Warszawa 2014.

Kąkol M., Z badań nad warunkami adaptacji dzieci trzyletnich do przedszkola, Wychowanie w Przedszkolu, 1988, 2.

Kąkol M., Z badań nad warunkami adaptacji dzieci trzyletnich w przedszkolu, [w:] Adaptacja dziecka do przedszkola i szkoty, red. M. Kąkol, Oddział Doskonalenia Nauczycieli, Szczecin 1990.

Kienig A., Przystosowanie dzieci trzyletnich do przedszkola, [w:] Edukacja przedszkolna na przełomie tysiacleci, red. S. Guz, Wyższa Szkoła Pedagogiczna TWP, Warszawa 2001.

Kienig A., Proces wczesnej adaptacji do przedszkola - wspieranie kompetencji społecznych matego dziecka, [w:] Wspieranie rozwoju dzieci w procesie wczesnej edukacji, red. W. Puślecki, Wydawnictwo Naukowe Dolnośląskiej Szkoły Wyższej, Wrocław 2008.

Koć-Seniuch G., Od kwalifikacji do kompetencji nauczycielskich, [w:] Nauczyciel i uczniowie $w$ dyskursie edukacyjnym. Wybrane problemy do zajęć konwersatoryjnych z pedagogiki, red. G. Koć-Seniuch, A. Cichocki, Trans Humana, Białystok 2000.

Kopik A., Brzezińska A., Kaczan R., Matejczuk J., Rycielski P., Rekomendacje dla praktyki edukacyjnej. Droga edukacyjna sześciolatków - szkoła czy przedszkole, Instytut Badań Edukacyjnych, Warszawa 2011.

Krauze-Sikorska H., Kuszak K., Przedszkole - obszary działań edukacyjnych i profilaktycznych, [w:] Wybrane problemy psychospotecznego funkcjonowania dzieci i młodzieży z utrudnieniami w rozwoju, red. H. Krauze-Sikorska, K. Kuszak, WSPIA, Poznań 2008.

Kuszak K., Dziecko samodzielne w szkole. Empiryczne studium szkolnych losów dzieci o różnym poziomie samodzielności, Oficyna Wydawnicza Garmond, Poznań 2008.

Laewen H., Andres B., Hedervari E., Die ersten Tage in der Krippe, Luchterhand, Heidelberg 2000.

Lewandowska-Kidoń T., Kompetencje nauczyciela szkoty wspótczesnej, [w:] Nauczyciel kompetentny teraźniejszość i przyszłość, red. Z. Bartkowicz, M. Kowaluk, M. Samujło, Wydawnictwo UMCS, Lublin 2007.

Lubomirska K., Przedszkole. Rzeczywistość i szansa, Wydawnictwo Akademickie Żak, Warszawa 1994.

Lubowiecka J., Przystosowanie psychospołeczne dziecka do przedszkola, Wydawnictwo Szkolne i Pedagogiczne, Warszawa 2000.

Lubowiecka J., Trudności adaptacyjne dziecka w przystosowaniu się do przedszkola, Wychowanie w Przedszkolu, 2001, 6.

Lubowiecka J., Przystosowanie dziecka do przedszkola zadaniem rozwojowym dla dziecka, [w:] Adaptacja w przebiegu życia jednostki, red. R. Michalak, Wyższa Szkoła Zawodowa „Kadry dla Europy”, Poznań 2010. 
Lubowiecka J., Suświłło M., Wybrane problemy wczesnej edukacji, WSP, Olsztyn 1997.

Michalak R., Adaptacja przez rozwiązywanie kryzysów rozwojowych, [w:] Adaptacja w przebiegu życia jednostki, red. R. Michalak, Wyższa Szkoła Zawodowa „Kadry dla Europy”, Poznań 2010.

Muchacka B., Okresy krytyczne na poszczególnych etapach edukacyjnych - doświadczenie osobiste i potencjalne możliwości dziecka, [w:] Wspieranie rozwoju dzieci w procesie wczesnej edukacji, red. W. Puślecki, Wydawnictwo Naukowe DSW, Wrocław 2008.

Nadrowska K., Pięciolatki w cieniu sześciolatków, czy sześciolatki w cieniu pięciolatków - zagrożenia rozwoju starszych przedszkolaków, [w:] Edukacja małego dziecka. Konteksty rozwojowe $i$ wychowawcze, t. 4, red. E. Ogrodzka-Mazur, U. Szuścik, J. Oleksy, Oficyna Wydawnicza Impuls, Kraków, 2013.

Piwowarska-Krukowska H., Adaptacja dzieci w przedszkolu, Wychowanie w Przedszkolu, 2007, 5.

Pomoc społeczna i opieka nad dzieckiem i rodzina w 2012 r., Warszawa 2013, www.gus.gov.pl, [dostęp: 29.07.2014].

Quality Targets in Services for Young Children, 1996.

Ratajczak A., Instytucjonalna opieka nad matym dzieckiem. Aktualny stan - perspektywy, [w:] Świat małego dziecka, t. 1, red. H. Krauze-Sikorska, M. Klichowski, K. Kuszak, Wydawnictwo Naukowe UAM, Poznań 2013.

Recommendation on Child Care 1992.

Schaffer H.R., Psychologia dziecka, Wydawnictwo Naukowe PWN, Warszawa 2005.

Sochaczewska G., Środowiskowo - wychowawcze uwarunkowania procesu adaptacji dzieci 3-4letnich do przedszkola, [w:] Materiaty do nauczania psychologii, seria II, t. 9, red. L. Wołoszynowa, PWN, Warszawa 1982.

Styczyńska M., Rola mężczyzny w wychowaniu dziecka w wieku przedszkolnym, [w:] Dziecko sukcesy i porażki, red. R. Piwowarski, Instytut Badań Edukacyjnych, Warszawa 2007.

Wall W.D., Twórcze wychowanie w okresie dzieciństwa, PWN, Warszawa 1986. 